\title{
PERBEDAAN LATAR BELAKANG PENDIDIKAN DAN MASA KERJA GURU BIMBINGAN DAN KONSELING TERHADAP PELAKSANAAN LAYANAN BIMBINGAN DAN KONSELING FORMAT KLASIKAL
}

\author{
Vivi Isari \\ Universitas Negeri Padang \\ Z. Mawardi Efendi \\ Universitas Negeri Padang \\ Neviyarni \\ Universitas Negeri Padang
}

\begin{abstract}
Abstrak
Penelitian ini berkenaan dengan keberadaan guru BK yang tidak memiliki latar belakang pendidikan bimbingan dan konseling. Mereka diangkat oleh kepala sekolah karena dianggap bisa dan berasal dari sarjana pendidikan dan non kependidikan yang mempunyai jam mengajar sedikit. Hal ini tentunya berdampak pada kualitas pelaksanaan layanan bimbingan dan konseling di sekolah. Penelitian ini bertujuan: (1) untuk mengungkap dan mendeskripsikan pelaksanaan layanan bimbingan dan konseling oleh guru BK; (2) perbedaan pelaksanaan layanan bimbingan dan konseling format klasikal ditinjau dari latar belakang SI BK dan Non BK; (3) perbedaan pelaksanaan layanan bimbingan dan konseling format klasikal ditinjau dari masa kerja < 16 tahun dan $\geqslant 16$ tahun; (4) interaksi latar belakang pendidikan dan masa kerja guru BK dalam memberikan layanan bimbingan dan konseling format klasikal.

Penelitian ini menggunakan metode kuantitatif dengan pendekatan deskriptif komperatif. Subjek penelitian adalah seluruh guru BK berlatar belakang SI BK dan Non BK kabupaten Sijunjung yang berjumlah 32 orang. Instrumen yang digunakan yakni skala model Likert dengan realibitas 0.965 dan validitas 0.507 (pelaksanaan layanan bimbingan dan konseling format klasikal). Data dianalisis dengan menggunakan teknik analisis varian (ANOVA).

Hasil analisis data menunjukkan: 1) pelaksanaan layanan bimbingan dan konseling format klasikal yang diberikan oleh guru berlatar pendidikan S1 BK dan Non BK dengan masa kerja < 16 tahun dan $\geqslant 16$ tahun berada pada kategori tinggi, dan rerata skor pelaksanaan layanan bimbingan dan konseling format klasikal bergategori sama. 2) tidak terdapat perbedaan yang signifikan ditinjau dari latar belakang pendidikan S1 BK dan Non BK. 3) tidak terdapat perbedaan secara signifikan dalam pelaksanaan layanan bimbingan dan konseling format klasikal ditinjau dari masa kerja $<16$ tahun dan $\geqslant 16$ tahun. 4) tidak terdapat interaksi yang signifikan antara skor latar belakang pendidikan dan masa kerja guru BK terhadap pelaksanaan layanan bimbingan dan konseling format klasikal.
\end{abstract}

Kata Kunci: Latar Belakang Pendidikan, Masa Kerja Guru Bimbingan dan Konseling dan Pelaksanaan Layanan Bimbingan dan Konseling Format Klasikal.

\section{Abstract}

This study is concerned with the presence of BK teachers who have no educational background in guidance and counseling. They are appointed by the principal because they are deemed to be and come from educational and non-educational graduates with little teaching hours. This certainly has an impact on the quality of the implementation of guidance and counseling services in schools. This study aims: (1) to reveal and describe the implementation of guidance and counseling services by BK teachers; (2) differences in the implementation of guidance and counseling services classical format reviewed from the background SI BK and Non BK; (3) differences in the implementation of classical guidance counseling and counseling services in terms of working period of $<16$ years and $\geqslant 16$ years; (4) the interaction of education background and working period of BK teacher in providing guidance and counseling service of classical format.

This research uses quantitative method with comparative descriptive approach. The subjects of the study were all BK teachers with BK and Non BK BK Sijunjung who numbered 32 people. The instruments used are Likert model scale with 0.965 realib and 0.507 validity (implementation of classical counseling guidance and counseling service). Data were analyzed by using variance analysis technique (ANOVA).

The result of data analysis shows: 1) the implementation of guidance and counseling service of the classical format given by the teacher of education background S1 and Non BK with working period $<16$ years and $\geqslant 16$ years are in high category, and the average score of implementation of guidance and counseling service of classical format same category. 2) there is no significant difference in the background 
of BK and Non BK S1 education. 3) there is no significant difference in the implementation of classical counseling guidance and counseling services in terms of working period of $<16$ years and $\geqslant 16$ years. 4) there is no significant interaction between the education background score and the working period of the BK teacher towards the implementation of classical counseling guidance and counseling services.

Keywords: Educational Background, Master's Work Period Guidance and Counseling and Implementation of Guidance and Counseling Services Classical Format

\section{PENDAHULUAN}

Pendidikan formal merupakan salah satu upaya mencerdaskan kehidupan bangsa dan membangun warga masyarakat. Oleh karena itu, memajukan dan meningkatkan kualitas pendidikan khususnya di Kabupaten Sijunjung merupakan keharusan yang semestinya dilaksanakan dalam rangka peningkatan dan pengembangan generasi muda yang berkualitas.

Layanan bimbingan dan konseling format klasikal merupakan sarana yang esensial dan strategis disamping pelayanan pengajaran dan pelatihan bagi penyelenggaraan pendidikan. Layanan bimbingan dan konseling model format klasikal dapat meningkatkan wawasan, keterampilan, nilai, dan sikap peserta didik. Layanan bimbingan dan konseling juga memungkinkan peserta didik terbebaskan dari berbagai masalah baik yang menyangkut masalah belajar maupun kehidupan pribadi. Bimbingan dan konseling (selanjutnya disingkat BK) di sekolah saat ini sudah tampak lebih baik apabila dibandingkan dengan era sebelumnya. Pengakuan layanan bimbingan dan konseling sebagai suatu profesi sudah semakin mengkristal terutama dari pemerintah dan kalangan profesi lainnya, meskipun masih ada persepsi negatif tentang guru BK dari para guru mata pelajaran, kepala sekolah dan orangtua peserta didik seperti: guru BK tidak ada aktivitas dan guru pasif (Tohirin, 2007:12). Persepsi negatif dan tudingan-tudingan miring yang muncul terhadap guru BK antara lain disebabkan oleh tidak maksimalnya tugas, peran, fungsi, dan tanggung jawab dalam melaksanakan kewajibannya. Selain itu juga disebabkan oleh kompetensi guru BK yang meliputi kompetensi akademik dan kompetensi profesional yang belum singkron.

Berkenaan dengan keberadaan guru BK yang tidak memiliki latar belakang pendidikan bimbingan dan konseling sebenarnya telah disadari oleh pemerintah. Terbukti melalui Kementrian Pendidikan Nasional, pemerintah menerbitkan Permendiknas No. 27-Tahun 2008 tentang standar kualifikasi akademik dan kompetensi konselor. Pada peraturan tersebut tercantum sejumlah peraturan khusus untuk guru BK di sekolah. Permendiknas No. 27 tahun 2008 tentang standar kualifikasi akademik dan kompetensi konselor di pasal 1 ayat 1 menyatakan bahwa untuk dapat diangkat sebagai guru BK, seseorang wajib memenuhi standar kualifikasi akademik dan kompetensi konselor yang berlaku secara nasional. Kemudian penyelenggara pendidikan yang satuan pendidikannya mempekerjakan guru BK wajib menerapkan standar kualifikasi akademik dan kompetensi guru BK.

Kenyataan di lapangan masih ditemukan diberbagai sekolah SMP, MTs, MA, SMA, dan SMK yang guru BK bukan berlatar pendidikan bimbingan konseling. Mereka diangkat oleh kepala sekolah karena dianggap bisa dan berasal dari sarjana pendidikan dan non kependidikan yang mempunyai waktu jam mengajar sedikit. Hal ini tentu saja akan berimplikasi pada kualitas pelaksanaan layanan bimbingan dan konseling di sekolah.

Terkait dengan fenomena di atas, teramati bahwa masih ditemukan latar belakang pendidikan guru BK yang beragam dan pemahaman guru BK tentang pelaksanaan layanan bimbingan dan konseling masih belum tepat, hal ini diduga berkaitan dengan masa kerja guru BK. Pendapat ini didukung oleh pernyataan Tyler (1969:219) yang menyatakan bahwa.

It would have to be assumed that counseling is indeed a powerful sort experience if, through a relatively few contact hours, personality patterns developed over many years and shaped by innumerable previous influences were to be significantly modified.

Pendapat Tyler tersebut dapat disimpulkan bahwa pelaksanaan layanan bimbingan dan konseling dipengaruhi oleh faktor pengalaman yang dapat terbentuk oleh karena faktor waktu atau masa kerja dalam melaksanakan layanan bimbingan dan konseling. Senada dengan Tyler, berdasarkan pendapat Mohammad Thoha (dalam Sulung dan Sanusi, 2007:6) dapat disimpulkan bahwa kemampuan yang diperoleh melalui pengalaman kerja sangat berpengaruh terhadap kinerja. Semakin lama seseorang bekerja pada suatu bidang maka semakin banyak pengalaman yang diperolehnya.

Zainal Abidin (dalam Sulung dan Sanusi, 2007:7) dengan kesimpulan bahwa pengalaman kerja akan menetapkan, mengembangkan keterampilan dan pengetahuan kerja, sikap mental dan kebiasaan mental serta fisik yang tidak dapat diperoleh dari pelatihan. Lebih lanjut menurut Handoko (dalam Sulung dan Sanusi, 2007:7) pendidikan merupakan indikator yang mencerminkan kemampuan seseorang untuk dapat menyelesaikan suatu pekerjaan, dengan latar belakang pendidikan seseorang dianggap mampu menduduki suatu jabatan.

Lama bekerja merupakan pengalaman individu yang akan menentukan pertumbuhan dalam pekerjaan dan jabatan. (Ifdil, 2009) lebih lanjut Mapiare menyatakan, pertumbuhan jabatan dalam pekerjaan dapat dialami oleh seorang hanya apabila dijalani proses belajar dan berpengalaman, dan diharapkan orang yang bersangkutan memiliki sikap kerja yang bertambah maju kearah positif, memiliki kecakapan (pengetahuan) kerja yang bertambah baik serta memiliki keterampilan kerja yang bertambah dalam kualitas dan kuantitas (dalam Rakhmat, 2003:58).

Senada dengan pendapat tersebut, berdasarkan pendapat Robbins (1991:82) dapat disimpulkan bahwa masa kerja berkaitan dengan produktivitas kerja. Artinya ada 
hubungan antara produktivitas seseorang dengan masa kerja sehingga diasumsikan bahwa semakin lama seseorang bekerja dalam organisasi semakin tinggi pula produktivitasnya. Hal itu terjadi karena ia semakin berpengalaman dan keterampilannya meningkat.

Berdasarkan pendapat-pendapat yang disebutkan di atas, banyaknya pengalaman dikarenakan telah lama bekerja dan didukung dengan pendidikan yang tepat, maka pemahaman seseorang tentang pekerjaannya akan semakin baik. Dapat diduga, meskipun para guru BK telah berlatar belakang S1 bimbingan dan konseling, akan tetapi dikarenakan pengalaman masa kerjanya yang masih singkat maka pemahaman mereka tentang pelaksanaan layanan bimbingan dan konseling khususnya bimbingan format klasikal masih belum begitu baik. Seharusnya, guru BK berlatar S1 BK yang telah memiliki masa kerja $\geq$ 16 tahun akan memiliki kinerja yang lebih baik dibandingkan dengan guru yang berasal dari Non BK dengan masa kerja di $<16$ tahun tentang pelaksanaan layanan bimbingan dan konseling format klasikal.

Penelitian ini bertujuan untuk mendeskripsikan pelaksanaan layanan bimbingan dan konseling format klasikal oleh guru BK di sekolah. Secara khusus tujuan yang ingin dicapai adalah sebagai berikut.

1. Mengungkapkan pelaksanaan layanan bimbingan dan konseling format klasikal secara umum dan perbedaannya berdasarkan latar belakang pendidikan S1 BK dan Non BK.

2. Mengungkapkan pelaksanaan layanan bimbingan dan konseling format klasikal secara umum dan perbedaannya berdasarkan masa kerja $<16$ tahun dan $\geq 16$ tahun.

3. Interaksi latar belakang pendidikan dengan masa kerja guru BK secara simultan dalam memberikan layanan bimbingan dan konseling format klasikal di SMA-SMKN Kabupaten Sijunjung.

\section{METODE PENELITIAN}

Penelitian ini menggunakan pendekatan kuantitatif jenis deskriptif komparatif. Subjek penelitian adalah BK yang berlatar belakang pendidikan S1 BK dan Non BK yang bertugas pada SMAN/SMKN Kab. Sijunjung dengan jumlah masing-masing sekolah bervariasi, sebagaimana yang terdapat pada Tabel berikut.

\begin{tabular}{|c|c|c|c|c|c|c|c|c|}
\hline Sub Variabel & $\begin{array}{c}\text { Skor } \\
\text { Ideal }\end{array}$ & Tertinggi & Terndah & Total & $\begin{array}{c}\text { Nilai } \\
\text { Rata- } \\
\text { rata }\end{array}$ & Sd & $\begin{array}{c}\% \\
\text { rata- } \\
\text { rata }\end{array}$ & Ket \\
\hline $\begin{array}{c}\text { Perencanaan } \\
(9)\end{array}$ & 36 & 35 & 21 & 929 & 29.03 & 3.50 & 80.63 & $\mathrm{~T}$ \\
\hline $\begin{array}{c}\text { Pelaksanaan } \\
(30)\end{array}$ & 120 & 110 & 75 & 3063 & 95.72 & 8.81 & 79.76 & $\mathrm{~T}$ \\
\hline $\begin{array}{c}\text { Evaluasi } \\
(7)\end{array}$ & 28 & 28 & 13 & 711 & 22.22 & 3.68 & 79.35 & $\mathrm{~T}$ \\
\hline $\begin{array}{c}\text { Tindak Lanjut } \\
(4)\end{array}$ & 16 & 16 & 7 & 399 & 12.47 & 2000 & 77.90 & $\mathrm{~T}$ \\
\hline $\begin{array}{c}\text { Keseluruhan } \\
(50)\end{array}$ & 200 & 184 & 117 & 5102 & 159 & 15,4 & 79.5 & $\mathrm{~T}$ \\
\hline
\end{tabular}

Tabel 1. Jumlah sampel penelitian

\begin{tabular}{|c|c|c|}
\hline \multicolumn{3}{|c|}{ Sampel Penelitian } \\
\hline Pendidikan & S1 BK & 23 Orang \\
\cline { 2 - 3 } & Non BK & 9 Orang \\
\hline Masa kerja & $<16$ Tahun & 21 Orang \\
\cline { 2 - 3 } & $>16$ Tahun & 11 Orang \\
\cline { 2 - 3 } & Total & 32 Orang \\
\hline
\end{tabular}

Instrumen yang digunakan berupa angket dengan model Skala Likert. Uji validitas instrumen menggunakan Product Moment Correlation dengan mean koefisien korelasi 0.40 dan uji reliabilitas menggunakan rumus Alpha Cronbach dengan r 0.965.

Data yang terkumpul dianalisis dengan cara menghitung skor rata-rata pelaksanaan layanan bimbingan dan konseling format klasikal. Setelah deskripsi data tersebut, dihitung rentangan data atau interval. Irianto (2010:22) menjelaskan untuk menghitung rentangan data atau interval dapat dilakukan dengan menghitung data tertinggi dikurang data terendah lalu dibagi jumlah kelas, sehingga diperoleh kategori yang diklasifikasikan dengan kriteria pada tabel berikut.

Tabel 2. Tingkat pencapaian responden

\begin{tabular}{|c|c|c|c|c|}
\hline \multirow{2}{*}{ Keterangan } & \multicolumn{4}{|c|}{ Sub Variabel dan Butir Pernyataan } \\
\cline { 2 - 5 } & Perencanaan & Pelaksanaan & Evaluasi & $\begin{array}{c}\text { Tindak } \\
\text { Lanjut }\end{array}$ \\
\cline { 2 - 5 } & \multicolumn{4}{|c|}{ Skor } \\
\hline $\begin{array}{c}\text { Sangat } \\
\text { Tinggi }\end{array}$ & $\geq 44$ & $\geq 168$ & $\geq 40$ & $\geq 23$ \\
\hline Tinggi & 36 s.d 43 & 140 s.d 167 & 33 s.d 39 & 19 s.d 22 \\
\hline Sedang & 28 s.d 35 & 112 s.d 139 & 26 s.d 32 & 15 s.d 18 \\
\hline Rendah & 20 s.d 27 & 85 s.d 111 & 19 s.d 25 & 11 s.d 14 \\
\hline $\begin{array}{c}\text { Sangat } \\
\text { Rendah }\end{array}$ & 12 s.d 19 & 57 s.d 84 & 12 s.d 18 & 7 s.d 10 \\
\hline
\end{tabular}

(Agus Irianto, 2010:22)

Selanjutnya data yang diperoleh dianalisis dengan menggunakan Analisis Varian (ANOVA).

\section{HASIL DAN PEMBAHASAN}

1. Hasil

a. Deskripsi Data Pelaksanaan Layanan Bimbingan dan Konseling Format Klasikal

Data pelaksanaan layanan bimbingan dan konseling format klasikal oleh guru S1 BK dan Non BK diperoleh dari sampel (responden) yang keseluruhannya berjumlah 32 orang guru BK. Berikut penjabaran hasil data pelaksanaan layanan bimbingan dan konseling format klasikal.

Tabel 3. Deskripsi Data Pelaksanaan Layanan Bimbingan dan Konseling Format Klasikal 


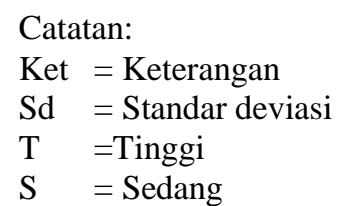

\begin{tabular}{|c|c|c|c|c|c|c|}
\hline $\begin{array}{l}\text { Sumber } \\
\text { Variansi }\end{array}$ & $S S$ & Dk & $M S$ & $\mathrm{~F}_{\text {hitung }}$ & Sig. & Ket. \\
\hline $\begin{array}{l}\text { Interaksi } \\
\text { Variabel } \\
\text { Kualifikasi } \\
\text { Pendidikan } \\
\text { SI } \\
\text { BK/Non } \\
\text { BK dan } \\
\text { Masa } \\
\text { Kerja }\end{array}$ & $558^{1 .}$ & 1 & $558^{1 .}$ & $06^{.0}$ & 939 & $\begin{array}{l}\text { Tidak } \\
\text { Signi } \\
\text { fikan }\end{array}$ \\
\hline
\end{tabular}

Berdasarkan tabel 3 di atas dapat diketahui bahwa secara keseluruhan skor ideal adalah sebesar 200, skor tertinggi 184, skor terendah 117 , skor total 5102 , dan standar deviasi sebesar 15.4. Dilihat pada sub variabel yaitu sub variabel perencanaan dengan rata-rata (mean) sebesar 29.03, sub variabel pelaksanaan berada pada kategori tinggi (T), dengan rata-rata (mean) sebesar 95.72, sub variable evaluasi juga berada pada kategori tinggi dengan rata-rata (mean) sebesar 22.22, dan sub variable tindak lanjut juga verada pada kategori tinggi dengan rata-rata (mean) 12.47. Dengan demikian secara keseluruhan skor pelaksanaan layanan bimbingan dan konseling yang diberikan oleh guru S1 BK dan Non BK berada pada kategori tinggi (T) dengan rata-rata(mean) sebesar 159.

a. Hasil Pengujian Hipotesis Anova Berdasarkan Variabel Kualifikasi Pendidikan S1 BK dan Non BK

Data penelitian yang diperoleh sebagai hasil dari pengujian hipotesis Anova berdasarkan kualifikasi pendidikan S1 BK dan Non BK dapat dilihat pada tabel berikut.

Tabel 4. Hasil pengujian hipotesis anova berdasarkan kualifikasi pendidikan S1 BK dan Non BK.

Tabel 4 di atas memberikan pemahaman bahwa pada variabel kualifikasi pendidikan guru S1 BK dan Non BK

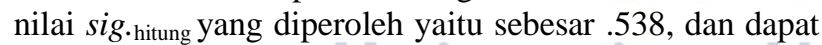
disimpulkan bahwa sig.hitung $>0.05$, sehingga $\mathrm{H} 1$ ditolak dan H0 diterima. Sesuai dengan kriteria pengujian hipotesis melalui analisis of varian (ANOVA), maka hal tersebut menunjukkan bahwa tidak terdapat perbedaan pelaksanaan layanan bimbingan dan konseling format klasikal oleh guru BK S1 BK dan Non BK.

\section{b. Hasil Pengujian Hipotesis Anova Berdasarkan Masa Kerja.}

Tabel. 5 Pengujian hipotesis anova berdasarkan masa kerja

\begin{tabular}{|l|c|l|l|l|l|l|}
\hline Skor Masa & 365.09 & 1 & 365.009 & 1.3 & .2 & Tid \\
Kerja & 9 & & & 88 & 4 & ak \\
$<16$ tahun & & & & & 9 & $\begin{array}{l}\text { Sig } \\
\text { nifi } \\
\text { kan }\end{array}$ \\
\hline
\end{tabular}

Tabel 5 memberikan pemahaman bahwa pada variabel masa kerja sig.hitung yang diperoleh yaitu sebesar .249 dapat disimpulkan bahwa sig.hitung $_{\text {. }}$.05, sehingga H0 diterima dan $\mathrm{H} 1$ ditolak. Sesuai dengan kriteria pengujian hipotesis melalui analisis ANOVA maka hal tersebut menunjukkan bahwa tidak terdapat perbedaan antara guru BK dengan masa kerja < 16 tahun dengan guru BK dengan masa kerja $\geq 16$ tahun dalam memberikan layanan bimbingan dan konseling format klasikal.

\section{c. Hipotesis Interaksi Variabel Kualifikasi Pendidikan SI BK/NonBK dan Masa Kerja}

Tabel 6. Interaksi latar belakang pendidikan dan masa kerja.

Catatan :

$\mathrm{SS}=$ Sum Squares

MS = Mean Squares

Dk = Derajat Kebebasan

\begin{tabular}{|l|l|l|l|l|l|l|}
\hline $\begin{array}{l}\text { Sumber } \\
\text { Varians } \\
\mathrm{i}\end{array}$ & $S S$ & MS & $\mathrm{F}_{\text {hitung }}$ & \multicolumn{1}{|c|}{$\mathrm{S}$} & Ket. \\
\hline Skor & 102 & & 10 & 388 &. & Tidak \\
S1 BK & .00 & 2.0 & & 538 & Signifikan \\
dan & 3 & 03 & & & \\
Non & & & & & & \\
BK & & & & & \\
\hline
\end{tabular}

Tabel 6 di atas memberikan pemahaman bahwa pada interaksi antara variabel kualifikasi pendidikan SI BK/Non BK dengan masa kerja nilai sig.hitung yang diperoleh yaitu sebesar .939, dan dapat disimpulkan bahwa sig $_{\text {.hitung }}>$.05, sehingga $\mathrm{H0}$ diterima dan $\mathrm{H} 1$ ditolak. Sesuai dengan kriteria pengujian hipotesis melalui analisis of varian (ANOVA), maka hal tersebut menunjukkan bahwa tidak ada interaksi antara kualifikasi pendidikan dan dengan masa kerja guru BK dalam memberikan layanan bimbingan dan konseling format klasikal di sekolah.

\section{PEMBAHASAN}

a. Gambaran Pelaksanaan Layanan Bimbingan dan Konseling Format Klasikal

Temuan penelitian ini mengungkapkan bahwa secara umum pelaksanaan layanan konseling format klasikal yang diberikan oleh guru SI BK dan Non BK dengan masa kerja $<16$ tahun dan $\geq 16$ tahun berada pada kategori tinggi. Skor yang cendrung ditempati oleh guru SI BK dan Non BK dengan masa kerja $<16$ tahun dan $\geq$ 16 tahun dengan rata-rata 159 dan persentase $79,5 \%$ yaitu pada kategori tinggi. Kemudian berdasarkan sub variabel pelaksanaan layanan bimbingan dan konseling format klasikal terdiri dari perencanaan, pelaksanaan, evaluasi dan tindak lanjut guru BK berada pada kategori sama yaitu pada kategori tinggi.

Tingginya kualitas pelaksanaan layanan bimbingan dan konseling format klasikal yang diberikan oleh guru S1 BK dan Non BK adalah suatu yang wajar dan malah 
diharapkan. Hal ini sejalan dengan pendapat Prayitno (1987:43) yang menyatakan bahwa:

Berhubung dengan pentingnya konseling dalam keseluruhan pelayanan bimbingan dan konseling, sewajarnyalah para petugas yang bergerak dalam lapangan bimbingan dan konseling membina diri dan memiliki secara mantap pemahaman dan penghayatan serta kemampuan dasar dan keterampilan yang menyangkut hubungan dan dinamika proses konseling yang setiap kali harus diselenggarakan antara konselor dan klien.

Pemahaman guru BK yang tinggi tentang proses pelaksanaan layanan bimbingan dan konseling format klasikal sejalan dengan Standar Kompetensi Konselor menurut Permendiknas nomor 27 tahun 2008, kompetensi pedagogik dijabarkan menjadi beberapa indikator, yaitu:

a. Menguasai teori dan praksis pendidikan tugas konselor adalah memberikan pelayanan kepada konseli. Seorang guru BK harus bisa menguasai teori yang ada berdasarkan landasan keilmuannya sehingga teori tersebut dapat digunakan untuk bekal guru BK dalam memberikan pelayanan kepada siswa. Dengan teori yang matang maka kemampuan dalam memberikan layanan pun akan lebih optimal.

b. Mengaplikasikan perkembangan fisiologis dan psikologis serta perilaku konseli. Dalam layanan konseling guru BK yang baik harus mengetahui dan mencatat setiap perkembangan yang ada yang terjadi pada konseli, baik yang bersifat fisiologis maupun psikologis. Data perkembangan tadi sangat berguna untuk menentukan pemberian layanan yang tepat dalam tahap konseling selanjutnya.

c. Menguasai esensi pelayanan bimbingan dan konseling dalam jalur, jenis, dan jenjang satuan pendidikan. Setiap guru BK profesional dituntut untuk fleksibel menguasai esensi pelayanan bimbingan dan konseling dalam semua jalur, jenis dan jenjang satuan pendidikan. Karena ruang lingkup guru BK sangatlah luas dalam bidang pendidikan. Dengan dikuasainya esensi pelayanan bimbingan dan konseling tersebut maka guru BK akan siap ditugaskan di mana saja yang sesuai dengan jalurnya.

Kaitan kompetensi pedagogik dengan penelitian yang dilakukan peneliti adalah kompetensi pedagogik merupakan bagian dari komponen pembentuk profesionalisme guru BK. Dengan memiliki kompetensi pedagogik yang baik guru BK mampu mengelola pembelajaran yang mendidik dan dialogis.

Temuan penelitian tentang tingginya pelaksanaan layanan bimbingan dan konseling format klasikal yang diberikan oleh guru BK berlatar belakang S1 BK dan Non BK tentang pelaksanaan layanan bimbingan dan konseling format klasikal, maka salah satu keresahan yang pernah diajukan pada bagian latar belakang tesis ini yaitu bagaimana pelaksanaan layanan bimbingan dan konseling format klasikal yang diberikan oleh guru BK berlatar belakang SI BK dan Non BK tidak optimal, tidak perlu dirisaukan lagi. Hasil penelitian ini telah menjawab persoalan tersebut khususnya untuk guru BK di Kabupaten Sijunjung.

\section{b. Gambaran Pelaksanaan Layanan Bimbingan dan Konseling Format Klasikal Ditinjau dari Kualifikasi Pendidikan (S1 BK dan Non BK)}

Hasil analisis data menunjukkan bahwa tidak terdapat perbedaan kualifikasi pendidikan S1 BK dan Non BK terhadap pelaksanaan layanan bimbingan dan konseling format klasikal adalah 0,538 lebih besar dari 0,05. Maka, H0 "Adakah perbedaan kualifikasi pendidikan S1 BK dan Non BK terhadap pelaksanaan layanan bimbingan dan konseling format klasikal" ditolak dan dapat disimpulkan bahwa tidak ada perbedaan signifikan antara kualifikasi pendidikan S1 BK dan non BK terhadap pelaksanaan layanan bimbingan dan konseling di sekolah. Dengan demikian temuan penelitian tidak bersesuaian dengan hipotesis penelitian.

Temuan penelitian ini memang agak menarik, karena guru BK berlatar belakang S1 BK mestinya memiliki tingkat pelaksananaan layanan bimbingan dan konseling yang lebih baik dibandingkan dengan guru berlatar belakang Non BK tentang layanan konseling format klasikal. Saroni (2011:205) bahwa seorang guru dalam proses pendidikan dan pembelajaran yang mempunyai latar belakang kualifikasi pendidikan yang sesuai tentunya mempunyai kelayakan yang lebih dibandingkan dengan yang tidak termasuk dalam bidang pendidikan. Selanjutnya Ambar (2005:138) menyatakan bahwa guru berlatar belakang SI BK seharusnya memiliki kemampuan yang lebih baik dalam pelaksanaan layanan bimbingan dan konseling karena telah dibekali dengan keilmuan dan pengetahuan yang khusus. Adanya kesamaan kinerja guru berlatar S1 BK dan Non BK dalam memberikan pelayanan bimbingan dan konseling format klasikal dapat dipengaruhi oleh oleh beberapa hal, yaitu: kompetensi pedagogik guru BK dalam penelitian ini sebagian besar adalah guru BK berlatar belakang pendidikan S1 BK memiliki kinerja pada kategori tinggi, sedangkan untuk guru berlatar pendidian Non BK juga memiliki kinerja yang tinggi dalam memberikan pelayanan bimbingan dan konseling format klasikal, jadi yang menyebabkan persamaan kinerja guru BK yang berlatar pendidikan S1 BK dan Non BK dalam penelitian ini adalah pada aspek kompetensi pedagogik.

Kompetensi pedagogik guru BK di kabupaten Sijunjung pada umumnya adalah berlatar belakang pendidikan $\mathrm{S}$, sehingga mereka pada umumnya sudah memiliki kompetensi pedagogik yang standar untuk untuk profesi guru. Standar pendidikan guru BK adalah S1 BK. Karena kompetensi pedagogik itu sudah memiliki kemampuan merancanakan pembelajaran, melaksanakan pembelajaran dan mengevaluasi pembelajaran. Keterampilan mengajar dan mengelola kelas yang baik, sehingga dimungkinkan kompetensi ini tidak mempengaruhi kinerja guru BK dalam pelaksanaan layanan bimbingan dan konseling format klasikal di SMA\&SMKN kabupaten Sijunjung.

Temuan penelitian ini menyimpulkan bahwa tidak terdapat perbedan kinerja guru berlatar pendidikan S1 BK dan Non BK dalam memberikan layanan bimbingan dan konseling format klasikal, hanya sebatas pada 4 (empat) layanan bimbingan dan konseling saja. Untuk layanan bimbingan dan konseling perorangan, layanan bimbingan kelomok, layanan konseling kelompok, layanan 
konsultasi, layanan mediasi dan layanan advokasi masih perlu penelitian lebih lanjut.

\section{c. Gambaran Pelaksanaan Layanan Bimbingan dan Konseling Format Klasikal Ditinjau dari Masa Kerja ( $<16$ tahun dan $\geq 16$ tahun)}

Hasil uji ANOVA didapat nilai signifikan untuk pelaksanaan layanan bimbingan dan konseling format klasikal berdasarkan masa kerja $<16$ dan $\geq 16$ tahun adalah 0, 249 lebih besar dari 0,05. Maka H0 ada perbedaan masa kerja yang signifikan terhadap pelaksanaan layanan bimbingan dan konseling format klasikal ditolak dan dapat disimpulkan tidak ada perbedaan signifikan antara masa kerja $<16$ dan $\geq 16$ tahun terhadap pelaksanaan layanan bimbingan dan konseling.

Hasil penelitian memperlihatkan bahwa rata-rata pelaksanaan layanan bimbingan dan konseling oleh guru BK dengan masa kerja $<16$ dan $\geq 16$ tahun berada pada tingkat yang sama pada kategori sama, sehingga guru BK dengan masa kerja $<16$ dan $\geq 16$ tahun memiliki kualitas yang sama. Hasil dari penelitian ini menunjukkan bahwa masa kerja guru BK dalam menjalankan tugasnya tidak memiliki perbedaan secara signifikan. Dengan demikian temuan penelitian tidak bersesuaian dengan hipotesis penelitian.

Temuan penelitian guru BK berlatar belakang S1 BK dengan masa kerja $\geq 16$ tahun mestinya memiliki kinerja yang lebih baik dalam pelaksanaan layanan bimbingan dan konseling daripada guru BK berlatar belakang S1 Non BK dengan masa kerja < 16 tahun. Hal ini berdasarkan pendapat Mohammad Thoha (dalam Sulung dan Sanusi, 2007:6) dengan kesimpulan bahwa kemampuan yang diperoleh melalui pengalaman kerja sangat berpengaruh terhadap kinerja. Semakin lama seseorang bekerja pada suatu bidang maka semakin banyak pengalaman diperolehnya.

Pendapat Zainal Abidin (dalam Sulung dan Sanusi, 2007:7) dapat disimpulkan bahwa pengalaman kerja akan menetapkan, mengembangkan keterampilan dan pengetahuan kerja, sikap mental dan kebiasaan mental serta fisik yang tidak dapat diperoleh dari pelatihan. Syarat pengalaman dinyatakan menurut pekerjaan yang harus dan dilakukan lama melaksanakan pekerjaan tersebut. Lebih lanjut menurut Handoko (dalam Sulung da Sanusi, 2007:7), pendidikan merupakan indikator yang mencerminkan kemampuan seseorang untuk dapat menyelesaikan suatu pekerjaan, dengan latar belakang pendidikan seseorang dianggap mampu menduduki suatu jabatan.

Lama bekerja merupakan pengalaman individu yang akan menentukan pertumbuhan dalam pekerjaan dan jabatan. Seperti diungkapkan oleh Mapiare, pertumbuhan jabatan dalam pekerjaan dapat dialami oleh seseorang apabila dijalani proses belajar dan berpengalaman, sehingga diharapkan orang yang bersangkutan memiliki sikap kerja yang bertambah maju ke arah positif, memiliki kecakapan (pengetahuan) kerja yang bertambah baik serta memiliki keterampilan kerja yang bertambah dalam kualitas dan kuantitas (dalam Rahmat, 1996).

Senada dengan pendapat tersebut, berdasarkan pendapat Robbins (1991:82) dapat disimpulkan bahwa masa kerja berkaitan dengan produktivitas kerja. Artinya ada hubungan antara produktivitas seseorang dengan masa kerja dan asumsi bahwa semakin lama seseorang bekerja dalam organisasi semakin tinggi pula produktivitasnya. Hal itu terjadi karena ia semakin berpengalaman dan keterampilannya meningkat. Berdasarkan pendapat yang telah dikemukakan sebelumnya, dengan pengalaman yang tinggi dikarenakan lamanya bekerja dan didukung dengan pendidikan yang tepat, maka seharusnya pemahaman seseorang tentang pekerjaannya akan semakin baik. Begitu juga seharusnya dengan tingkat pelaksanaan layanan bimbingan dan konseling format klasikal yang diberikan guru BK berlatar S1 BK masa kerja $<16$ tahun dan masa kerja $\geq 16$ tahun.

Namun demikian sebagaimana dikemukakan oleh Munandir (dalam Marjohan, 1994:110) bahwa peningkatan unjuk kerja profesional BK tidak saja berhubungan dengan dengan soal penguasaan metode, teknik atau keterampilan saja, tetapi juga menyangkut persoalan sikap, motivasi, nilai pribadi konselor, dan soal pemaknaan oleh guru BK akan tugasnya. Jadi tidak ditemukannya perbedaan pelaksanaan layanan bimbingan dan konseling format klasikal oleh guru BK dengan masa kerja $<16$ tahun dengan masa kerja $\geq 16$ tahun diduga disebabkan oleh faktor-faktor sikap, motivasi, nilai pribadi dan pemaknaan guru BK akan tugas-tugas yang diembannya. Untuk dapat membuktikan persoalan tersebut ada baiknya dilakukan penelitian yang lebih mendalam berkenaan dengan hal yang dimaksudkan.

Faktor lain yang diduga menyebabkan tidak adanya perbedaan pelaksanaan layanan bimbingan dan konseling format klasikal guru BK dengan masa kerja < 16 tahun dan masa kerja $\geq 16$ tahun adalah karena guru BK kurang mendapatkan pendidikan dalam jabatan (in-service training), seminar, pelatihan ataupun workshop berkenaan dengan proses pelaksanaan layanan bimbingan dan konseling. Dikarenakan para guru BK kurang mendapatkan pendidikan dalam jabatan, jarangnya kegiatan seminar, pelatihan ataupun workshop berkenaan dengann layanan bimbingan dan konseling format klasikal, menyebabkan para guru BK terbelenggu hanya dalam pemahaman yang mereka peroleh selama mengikuti pendidikan S1 bimbingan dan konseling yang telah mereka lewati puluhan tahun lalu. Diduga para guru BK lupa atau mungkin justru belum begitu memahami bagaimana sebenarnya pelaksanaan layanan bimbingan dan konseling.

d. Gambaran Interaksi Pelaksanaan Layanan Bimbingan dan Konseling Format Klasikal Ditijau dari Kualifikasi Pendidikan dan Masa Kerja Guru BK

Hasil uji ANOVA didapat nilai signifikan untuk interaksi guru BK berdasarkan kualifikasi pendidikan dan masa kerja adalah sebesar 0,939 lebih besar dari 0,05. Maka H0, "Terdapat keterkaitan antara kualifikasi pendidikan dan masa kerja terhadap optimalsisasi pelaksanaan layanan bimbingan dan konseling" ditolak dan dapat disimpulkan bahwa tidak ada keterkaitan antara kualifikasi pendidikan dan masa kerja terhadap pelaksanaan layanan bimbingan dan konseling oleh guru BK di Kabupaten Sijunjung. Hasil penelitian ini 
menunjukkan bahwa tidak ada keterkaitan antara kualifikasi pendidikan dan masa kerja terhadap optimalisasi pelaksanaan layanan bimbingan dan konseling format klasikal.

Sebagaimana yang diamanatkan Undang-undang Republik Indonesia Nomor 14 tahun 2005 tentang Guru dan Dosen. Menurut Rusman (2010:19) guru yang memiliki kinerja yang baik, merupakan orang yang terdidik dan terlatih dengan baik, serta memiliki pengalaman yang luas dalam bidangnya. Dengan demikian, pengetahuan, pengalaman seseorang dalam mengajar, peningkatan mutu kualitas melalui pelatihan, pengembangan karir, dan penghargaan dalam bekerja merupakan usaha untuk meningkatkan kualitas.

Berdasarkan hasil penelitian Saroni (2011:206) mengungkapkan bahwa latar belakang pendidikan sudah memenuhi kualifikasinya, namun dalam aspek aktualisasi diri masih banyak guru yang belum dapat memenuhi tuntunan dalam bidang keguruan, disamping itu, pendidikan keprofesian dikaitkan dengan sertifikat berujung pada harapan kompensasi atau profesimya.

Suwardi (2007:23) ilmu pengetahuan bukanlah suatu yang statis dan seorang telah menjadi guru bukan berarti tugas pendidikannya selesai, akan tetapi ilmu pengetahuan selalu berkembang dan mengalami perubahan secara dinamis, jika guru khususnya guru BK tidak mampu menyeimbangi perkembangan ilmu pengetahuan akan tertinggal. Sedangkan menurut Suparno (2005:77) banyak guru yang tidak membaca dan mengembangkan pengetahuan dalam mengajar mereka, hal ini dapat dilihat, guru yang mengajar lebih dari 10 tahun menggunakan metode yang sama tanpa ada perubahan. Sejalan dengan hasil penelitian Supriadi, (1998:187) di beberapa negara, efektifitas guru mengajarnya dengan rentangan 4-20 tahun. Sedangkan yang lebih dari 20 tahun mengajar kurang menjadi kurang efektif karena faktor kejenuhan.

Berdasarkan hasil temuan dapat disimpulkan bahwa tidak ada keterkaitan antara kualifikasi pendidikan dan masa kerja guru BK terhadap pelaksanaan layanan bimbingan dan konseling format klasikal dilatarbelakangi oleh kurangnya pengembanan (kecendrungan monoton) personal guru dalam hal penguasaan kompetensi pedagogik dari waktu ke waktu selama guru itu mengabdikan diri di sekolah.

\section{KESIMPULAN}

Berdasarkan hasil penelititan, dapat disimpulan bahwa: pada Bab IV dapat disimpulan sebagai berikut. (1) tidak terdapat perbedaan yang signifikan pelaksanaan layanan bimbingan dan konseling format klasikal ditinjau dari latar belakang pendidikan S1 BK dan Non BK, dimana rerata skor guru S1 BK dan Non BK berada pada kategori sama. (2) tidak terdapat perbedaan pelaksanaan layanan bimbingan dan konseling format klasikal ditinjau dari masa guru $\mathrm{BK}<16$ tahun dan dan $\geq 16$ tahun, dimana rerata skor berada pada pada kategori sama-sama tinggi. (3) tidak terdapat interaksi latar belakang pendidikan guru BK dengan masa kerja terhadap pelaksanaan layanan bimbingan dan konseling format klasikal, artinya kesesuaian latar belakang pendidikan guru BK ditambah dengan lamanya masa kerja tidak terkait dengan kualitas pelaksanaan layanan bimbingan dan konseling.

\section{IMPLIKASI}

Hasil penelitian yang dilakukan terhadap guru BK berkualifikasi S1 BK dan Non BK dengan masa kerja < 16 tahun dan masa kerja $\geq 16$ tahun berada pada kategori rendah. Pelaksanaan layanan bimbingan dan konseling format klasikal yang diberikan oleh guru BK berkualifikasi S1 BK masa kerja $\geq 16$ tahun tidak terdapat perbedaan dengan guru Non BK dengan masa kerja <16 tahun, berdasarkan hasil penelitian tersebut perlu sekiranya diberikan pendidikan dalam jabatan (in-service training), seminar, pelatihan ataupun workshop berkenaan dengan pelaksanan layanan bimbingan dan konseling format klasikal sehingga kinerja guru BK menjadi semakin meningkat.

Dalam kaitan ini peranan pendidikan dalam jabatan (inservice training), seminar, pelatihan ataupun workshop dalam rangka menumbuhkembangkan berbagai konsep yang tepat, lengkap dan terpadu tentang keterampilan konseling khususnya layanan bimbingan dan konseling format klasikal adalah sangat penting. Hal tersebut seharusnya akan membantu guru BK sekolah dalam memadukan berbagai konsep tentang konseling dengan aspek praktek tentang konsep tersebut di lapangan. Pendidikan dalam jabatan (in-service training), seminar, pelatihan ataupun workshop seharusnya dapat memperkaya konsep guru BK di sekolah dan guru BK dapat mengaktualisasikan konsep tersebut ke dalam kegiatan praktek layanan bimbingan dan konseling format klasikal di sekolah. Hal tersebut tentunya juga diiringi oleh penciptaan iklim pendidikan dalam jabatan (inservice training), seminar, pelatihan ataupun workshop yang menumbuhkembangkan nilai-nilai dan syarat-syarat kepribadian guru BK yang profesional.

Lembaga Pendidikan Tenaga Kependidikan (LPTK) juga seharusnya lebih sering mengadakan seminar, pelatihan ataupun workshop berkenaan dengan pelaksanaan layanan bimbingan dan konseling format klasikal agar guru BK mendapatkan wawasan, pengetahuan, keterampilan, nilai dan sikap yang semakin tepat tentang pelaksanaan layanan bimbingan dan konseling format klasikal.

\section{SARAN}

Berdasarkan kesimpulan hasil penelitian tersebut, beberapa saran penting untuk dipertimbangkan yaitu.

1. Perlunya guru BK berlatar S1 BK dan Non BK untuk mengikuti pendidikan dalam jabatan (inservice training), pelatihan, seminar atau workshop terkait dengan pelaksanaan layanan bimbingan dan konseling format klasikal.

2. Faktor pengawasan terhadap guru BK perlu menjadi perhatian bagi Dinas Pendidikan, khususnya pengawas dalam bidang bimbingan dan konseling sehingga dedikasi para guru BK dapat terkontrol.

3. Lembaga Pendidikan Tenaga Kependidikan (LPTK) hendaknya menyeleksi calon guru BK yang akan menekuni profesi konseling dan model pendidikan calon guru BK harus dapat 
membina dan mengembangkan berbagai syarat kepribadian yang sesuai dengan tuntutan profesi konseling. Seleksi calon guru BK di samping memperhatikan kemampuan intelektual calon mahasiswa, hendaknya juga didasarkan kepada bakat, minat, dan syarat-syarat kepribadian yang betul-betul sesuai dengan tuntutan pekerjaan seorang guru BK.

4. Perlunya guru BK bekerja sama dengan seluruh personil sekolah dalam rangka menunjang pelaksanaan layanan bimbingan dan konseling format klasikal yang optimal.

5. Musyawarah Guru Bimbingan dan Konseling (MGBK) perlu melakukan seminar, pelatihan, ataupun workshop terkait dengan layanan bimbingan dan konseling format klasikal.

6. Peneliti selanjutnya, hasil penelitian ini dapat dikembangkan melalui penelitian lanjutan berkenaan pelaksanaan layanan bimbingan dan konseling format klasikal.

\section{DARTAR RUJUKAN}

ABKIN. 2005. Anggaran Dasar dan Anggaran Rumah Tangga, Kode Etik Bimbingan dan Konseling, Standar Kompetensi Konselor.

Akos, Patrick Caroline R Cockman, \& Cindy A Strickland, 2007. "Differentiating Classroom Guidance Proffesional School Counseling" ProQuest Education Journal

Arikunto, Suharsimi. 2006. Prosedur Penelitian Suatu Pendidikan Praktis. Jakarta: Rineka Cipta.

Binham. 2011. Makalah Layanan Orientasi dalam BK Karir untuk Kelas XI. (Online), Vol. 1, No.I (http://binham.wordpress.com/2010/04/21/makalahlayanan-orientasi dalam-bk-karir-untuk-kelas-XI, diakses 06 Maret 2014).

Clark, H.,H., \& Eve, V.C. 1977. Psychology and Language: An instruction to psycholinguistics. New York: Harcourt Brace Jovanovich International Edition.

Departemen Pendidikan Nasional. 2008. Penataan Pendidikan Profesional Konselor dan Layanan Bimbingan dan Konseling dalam Jalur Pendidikan Formal.

Depdikbud. 2005. Kurikulum Sekolah Menengah Umum tentang: Petunjuk pelaksanaan bimbingan dan konseling. Jakarta: Depdikbud.

Depdiknas. 2003. Dasar Standarisasi Profesi Konseling. Jakarta: LPT.

Depdiknas. 2003. Panduan Pelayanan Bimbingan dan Konseling (Kurikulum Berbasis Kompetensi). Jakarta: Balitbang Depdiknas.

Dinas Pendidikan Kabupaten Sijunjung. 2013. Data Guru PNS dan Non PNS SMP/SMA/SMK.

Gibson, R.,L., \& Mitchell, M.H. 1995. Introduction to Guidance. New York: Macmillan Publisher.

Gysbers, J. P., \& Henderson, P. (1998). Developing \& managing Your School Guidance and Counseling Program. Fourth Edition. Alexandria, VA: American Counseling Association.
Grounlund, N.E. 1977. Constructing Achievement Tests. USA: Prentice-Hall.

Hariyadi, Sugeng. 2000. "Persepsi Siswa SMA terhadap Tingkat Keefektifan Konselor dalam Memberikan Layanan Konseling Individual (Penelitian di SMA Negeri se-Kodya Semarang)". Tesis tidak diterbitkan. Semarang: IKIP Semarang Press.

Hartono. 2011. Program Pendidikan Profesional Konselor Masa Depan dan Tantangan di Era Globalisasi. (Online),

(http://ppb.jurnal.unesa.ac.id/bank/jurnal/4._Artikel Hartono.pdf, diakses 8 Mei 2013).

Hikmawati, Fenti. 2011. Bimbingan dan Konseling. Jakarta: Raja Grafindo Persada Kumpulan Naskah. 2013. Kurikulum 2013 dan Bimbingan dan Konseling. Padang: BK FIP UNP

Ifdil. 2009. "Pemahaman Guru Pembimbing Berlatar S1 BK tentang Proses Konseling Perorangan. Tesis tidak diterbitkan. Padang: Program Pasca sarjana UNP.

Irawan, Mirza. 2013. "Kesiapan Guru Bimbingan dan Konseling Menjalani Penilaian Kinerja Guru (Studi di SMA dan SMKN Kabupaten Batu Bara Provinsi Sumatera Utara)". Tesis tidak diterbitkan. Padang: Program S2 Bimbingan dan Konseling FIP UNP.

Irianto, Agus. 2010. Statistik: Konsep dasar, aplikasi dan pengembangannya. Jakarta: Kencana Preda Media Group.

Kartono. 2001. Pentingnya Bimbingan dan Konseling. Jakarta: Harian Kompas Press.

Mappiare, Andi. 1993. Psikologi Orang Dewasa. Surabaya: Usaha Nasional.

Mulyani. 2003. Hubungan Layanan Informasi Bimbingan Belajar dengan Minat Belajar Siswa di SMPN 3 Kulon Progo Yogyakarta. Jurnal Pendidikan, (Online), Vol. 3 No. I, (http://jurnal-pendidikanbelajarmutu, diakses 16 Maret 2015).

Pascasarjana. 2014. Buku Panduan Penulisan Tesis dan Disertasi. Padang: Program Pascasarjana UNP.

Peraturan Pemerintah Nomor 19 tahun 2005 Tentang Standar Nasional Pendidikan.

Permendiknas No.27 Tahun 2008 tentang Standar Kualifikasi Akademik dan Kompetensi Konselor.

Prayitno. 1997. Seri Pemandu Pelaksanaan Bimbingan dan Konseling di Sekolah Buku II Pelayanan Bimbingan dan Konseling (SLTP). Jakarta: Aksara.

Prayitno. 2001. Buku Panduan Pelayanan Bimbingan dan Konseling Berbasis Kompetensi. Padang: UNP Padang.

Prayitno. 2002. Penilaian Hasil Layanan Bimbingan dan Konseling. Padang: UNP.

Prayitno. 2006. Seri Kegiatan Pendukung Konseling. Padang: UNP.

Prayitno. 2009. Wawasan Profesional Konseling. Padang: Universitas Negeri Padang.

Prayitno. 2010. Seri Modul Pendidikan Profesi Guru. Padang: FIP Jurusan Bimbingan dan Konseling UNP.

Prayitno. 2012. Jenis Layanan dan Kegiatan Pendukung Konseling (Pendidikan Profesi Konseling). Padang: FIP UNP. 
Rahmat, Jalaludin. 2003. Psikologi Komunikasi. Bandung: Remaja Karya.

Riduwan. 2004. Penanganan Efektif Bimbingan dan Konseling di Sekolah. Yogyakarta: Pustaka Belajar.

Rivai. 2005. Performance Appraisal System untuk Menilai Kinerja Karyawan dan Meningkatkan Daya Saing Perusahaan. Edisi Kedua. Jakarta: Rajagrafind.

Robbins, S.P. 1991. Organizational Bahavior. Fifth Edition. New Jersey: Prentice Hall, Englewood Cliff.

Rusman. 2010. Profesinalisme Guru. Jurnal, (Online), Vol 2, No. II, (https://stkippgrillg.files.wordpress.com/2010/02/pro fesionalismeguru.ppt, diakses 1 Maret 2015).

Saroni, Mohammad. 2011. Personal Branding Guru. Yogyakarta: Ar-Ruzz Media.

Sugiyono. 2005. Statistika untuk Penelitian. Bandung: Alfabeta.

Sugiyono. 2013. Metodologi Penelitian Pendidikan. Bandung. Alfabeta.

Suhertina. 2008. Pengantar Bimbingan dan Konseling di sekolah. Pekanbaru: Suska Press.

Sukardi, Dewa Ketut. 2002. Pengantar Pelaksanaan Program Bimbingan dan Konseling di Sekolah. Jakarta: Rineka Cipt

Sukardi, Dewa Ketut \& Kusmawati, Desak Nila. (2008). Proses Bimbingan dan Konseling di Sekolah. Jakarta: Rineka Cipta.

Sulung, Neila \& Sanusi, Rossi. 2007. Hubungan antara Motivasi dan Kinerja Dosen Jurusan Kebidanan Politeknik Kesehatan Padang. Jurnal Working Paper Series (WPS), (Online), Vol. 2. No I, (http://jsde.cxfordjournals.org/, diakses Maret 2014).

Suparno. 2007. Kinerja Guru Pembimbing Khusus Ditinjau dari Latar Belakang Pendidikan. Jurnal, (Online), Vol. 4, No. II, (https://aminsilalahi.files.wordpress.com/.../artikelpenelitan-laililaflahkul, diakses 26 Februari 2014).

Supriadi, Danang. 1998. Mengangkat Citra dan Martabat Guru. Yogyakarta: Mitra Gama Widya.

Suwardi. 2007. Manajemen Pembelajara: Mencipta guru kreatif dan berkompetisi. Surabaya: Temprina Media Grafika.

Tohirin. 2003. Psikologi Pembelajaran Agama Islam. Pekanbaru: Sarana Mandiri Offset.

Tohirin. 2007. Bimbingan dan Konseling di Sekolah dan Madrasah Berbasis Integritas. Jakarta: Rajawali Pers.

Tohirin. 2013. Bimbingan dan Konseling di Sekolah dan Madrasah. Jakarta: Rajawali Pers.

Tyler, L.E. 1969. The Work of The Counselor. New York: Appleton- Century-Crofts, Inc.

Undang-undang Nomor 14 Tahun 2005 tentang Guru dan Dosen. Jakarta: Kementrian Pendidikan Nasional.

Undang-undang Nomor 20 Tahun 2003 tentang Sistem Pendidikan Nasional. Jakarta: Kementrian Pendidikan Nasional.

Widiyanto, Mikha Agus. 2013. Statistika Terapan. Jakarta: Kompas Gramedia.

Winkel, W.S. 2004. Bimbingan dan Konseling di Institusi Pendidikan. Jakarta: Gramedia.
Yamin, H. Martinis. 2007. Kiat Membelajarkan Siswa. Jakarta: Gaung Persada Press.

Yusuf, A. Muri. 2005. Metodologi Penelitian. Padang: UNP Press.

Yusuf, A. Muri. 2008. "Manajemen Pelayanan Konseling di Sekolah". Makalah disajikan dalam Konvensi Nasional II IKI dan Seminar Internasional Konseling, Universitas Negeri Padang, 15 Maret 2014.

Yusuf, A. Muri. 2013. Metode Penelitian: Kuantitatif, kualitatif, dan penelitian gabungan. Padang: UNP Press.

Zuriah, Nurul. 2006. Metode Penelitian Pendidikan. Bandung: Alfabeta. 